\title{
THE CONTROL OF METHEMOGLOBINEMIA WITH METHYLENE BLUE ${ }^{1,2}$
}

\author{
By WILLIAM B. WENDEL \\ (From the Department of Internal Medicine, Washington University School of Medicine, St. \\ Louis; and the Department of Chemistry, University of Tennessee, \\ College of Medicine, Memphis)
}

(Received for publication October 13, 1938)

The cyanosis seen in a high percentage of patients receiving sulfanilamide and related drugs has been attributed variously to methemoglobinemia $(1,2)$, sulfhemoglobinemia $(1)$, an unusual degree of unsaturation of the venous blood (3), and to the presence of aniline black (4) and other colored derivatives of sulfanilamide (5) in the red blood corpuscles. Marshall and Walzl (4) and Chesley (6) consider methemoglobin to be of no importance except perhaps in an occasional patient.

The present paper summarizes the results of determinations of methemoglobin in the blood of more than one hundred patients who were receiving sulfanilamide and showing cyanosis. Methemoglobin was found, at least in traces, in over 90 per cent of these. In thirty-five cases the blood contained methemoglobin to the extent of 15 per cent or more of the total pigment. In one instance 40 per cent of the total blood pigment was in the form of methemoglobin

Animal experiments are described which confirm and extend the observations of Williams and Challis (7), Steele and Spink (8), and Hauschild (9) that methylene blue hastens disappearance of methemoglobin from the blood. Clinical application of these experiments to patients showing cyanosis from sulfanilamide has shown that intravenous injection of 0.1 to $0.2 \mathrm{cc}$. of one per cent methylene blue per kilogram body weight reduces

1 A preliminary report of this work was given before the Middle Section of the American Laryngological, Rhinological, and Otological Society, St. Louis, January 26, 1938, and the American Society of Biological Chemists, Baltimore, March 30, 1938 (J. Biol. Chem., 1938, 123, cxxiv), and was contained in a letter to the Editor of the J. A. M. A., 1937, 109, 1216.

2 This work was supported at both schools by grants from the Upjohn Company, Kalamazoo, Michigan. The Upjohn Company has supplied the writer with $10 \mathrm{cc}$. ampoules of methylene blue which were used in the clinical studies. the concentration of methemoglobin from levels as high as 25 to 40 per cent of the total pigment to less than 4 per cent in 30 to 40 minutes.

In one case of sulfhemoglobinemia methylene blue was without effect upon the abnormal pigment.

\section{ANIMAL OBSERVATIONS}

Since, in our experience, sulfanilamide does not produce methemoglobin in dogs, rabbits, rats, and mice, nitrite was used to produce experimental methemoglobinemia. Figure 1 illustrates the course of blood pigment changes in seven control dogs which received intravenous injections of 30 mgm. of sodium nitrite per kilogram of body weight. Following injection of nitrite, methemoglobin $^{3}$ rapidly accumulates and after 60 to 100 minutes reaches a maximum concentration corresponding to a loss of 60 to 70 per cent of the normal oxygen capacity. It then progressively decreases, due to reconversion to hemoglobin, and after 8 to 9 hours has entirely disappeared. The average maximum rate of regeneration of hemoglobin from methemoglobin (indicated in Figure 1 by a broken line) in these seven animals was 0.03 volumes per cent per minute. This is essentially the same rate as observed when blood containing methemoglobin from these animals is incubated at body temperature in vitro, and may be looked upon as the rate at which the enzyme systems in the erythrocytes are able to reduce methemoglobin (10).

3 Methemoglobin concentration is expressed in this paper in two ways, as per cent of the total pigment and as volumes per cent, one volume per cent of methemoglobin being that concentration which results from loss of one volume per cent oxygen capacity.

In most experiments methemoglobin was determined by a spectroscopic method which will appear in a forthcoming number of the J. Lab. and Clin. Med. Occasionally, methemoglobin was determined also by difference between total pigment and oxygen capacity. The two methods usually gave identical results. 


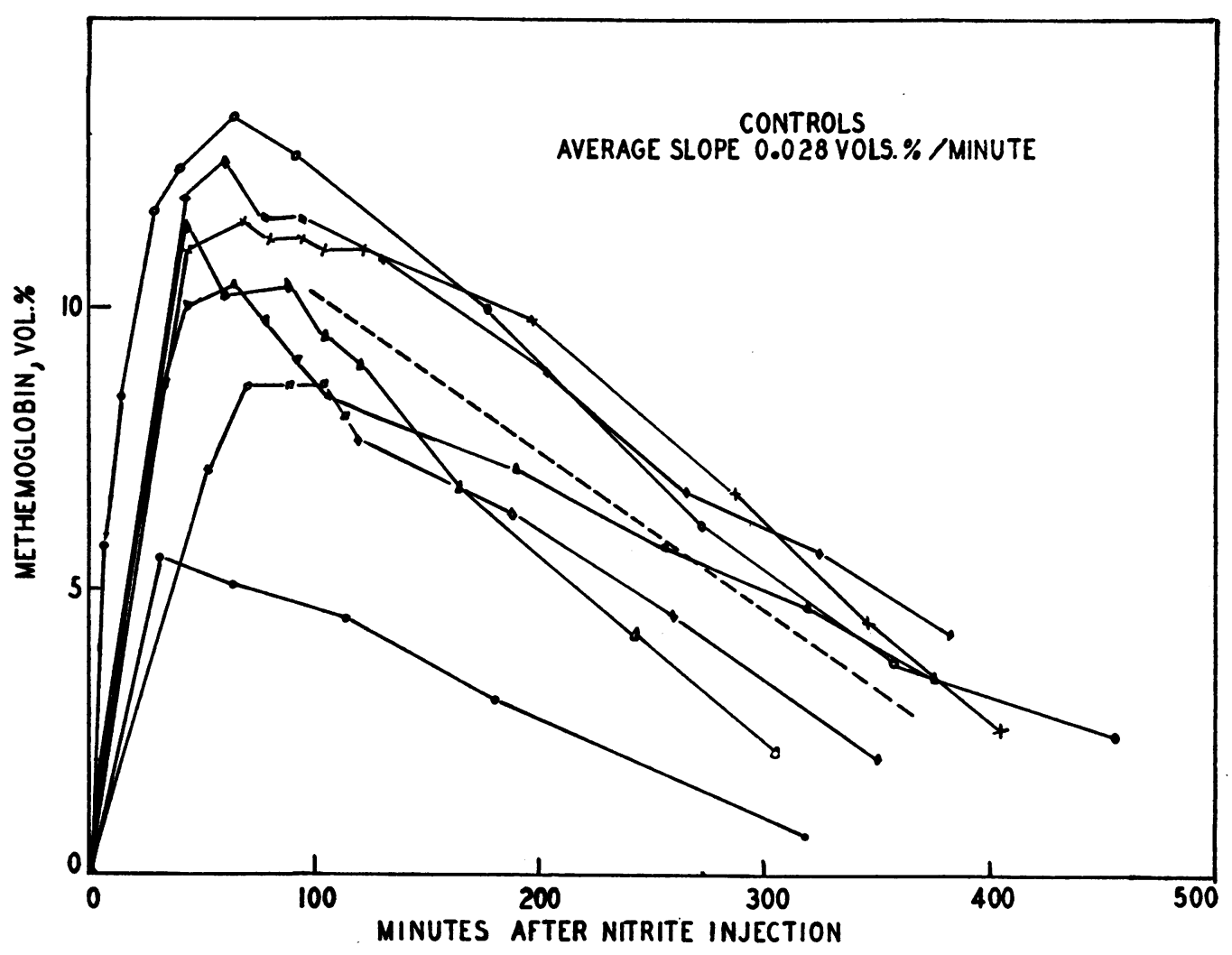

Fig. 1. Accumulation and Disappearance of Methemoglomin in the Blood of Dogs Following the Intranenous Injection of Sodium Nitrite (30 mgm. Per Kilogram of Body Weight)

Having determined the physiological rate of hemoglobin regeneration from methemoglobin various substances were tested for possible accelerating action upon this process. Sodium formaldehyde sulfoxylate, which reduces methemoglobin in aqueous solution, was found to be without effect in vivo. Sodium formaldehyde sulfoxylate, however, reduces methylene blue and since reduced (leuco) methylene blue converts methemoglobin to hemoglobin very rapidly, it seemed possible that simultaneous injection of these two substances might accelerate conversion of methemoglobin to hemoglobin. A cycle between sulfoxylate in the plasma and methemoglobin in the red cells mediated by methylene blue was pictured. When tested it was found that simultaneous intravenous injection of methylene blue and sulfoxylate caused methemoglobin to disappear from the blood very rapidly. Control experiments, however, showed that methylene blue alone was equally effective. Figure 2, which illustrates the results obtained with a number of dogs, shows that injection of $2 \mathrm{mgm}$. of methylene blue (in the form of a one per cent aqueous solution) per kilogram of body weight increases the rate of disappearance of methemoglobin from the blood four or fivefold. Table I summarizes the results of a series of similar experiments in which the effect of various quantities of methylene blue upon the rate of disappearance of methemoglobin from the blood was determined. A measurable effect is evident even with the smallest amount of dye injected, namely, $0.1 \mathrm{mgm}$. per kilogram of body weight. Oxygen capacity figures in Table $I$ indicate that the methemoglobin which disappears rapidly following injection of methylene blue is converted to functionally active hemoglobin. The duration of the anti-methemoglobin action of $5 \mathrm{mgm}$. of methylene blue per kilogram in dogs is at most about 2 hours.

Methylene blue accelerates the disappearance of methemoglobin also from the blood of rabbits. 


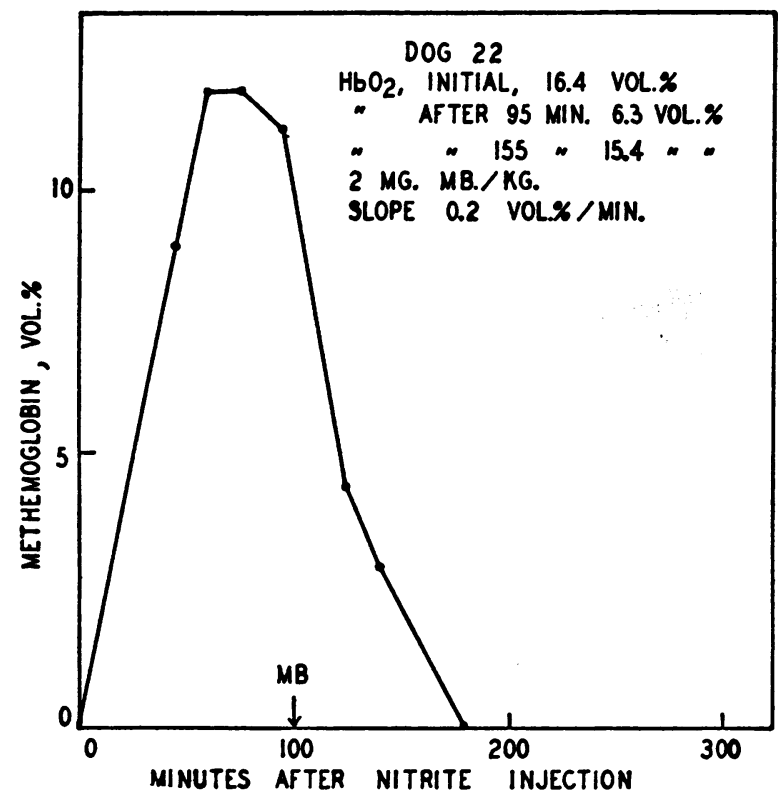

Fig. 2. Efrect of Intravenous Injection of MethyLENE BLUE, 2 MgM. PER KHLGRAM OF BODY Wetght, ON RAte of Conversion of Methemoglobin to Hemoglobin IN THE Dog

$\mathrm{HbO}_{2}$ means oxygen capacity. $\mathrm{MB}$ over arrow indicates injection of methylene blue.

\section{CLINICAL APPLICATION}

In collaboration with Dr. Alexis F. Hartmann of Washington University Medical School, where the writer began and completed an important part of this work, these observations received first clinical application in the summer of 1937. Since these early observations many others have been made with the cooperation of physicians on the staff of the University of Tennessee Medical School. In summary, intravenous injection of 0.1 to $0.2 \mathrm{cc}$. per kilogram of body weight of a one per cent aqueous solution of methylene blue converts in the course of about 45 minutes all of the methemoglobin in the circulating erythrocytes into functionally active hemoglobin, even when the methemoglobin concentration represents initially as much as 25 to 40 per cent of the total pigmenit. The rate at which methemoglobin reappears following injection of the dye varies with different individuals, but as a general rule the concentration of methemoglobin will have returned to its pre-methylene blue level not sooner than 12 hours and not later than 24 hours after injection of $2 \mathrm{mgm}$. of dye per kilogram of body weight.
Methylene blue is effective as an anti-methemoglobin agent also when given by mouth. As compared with intravenous injection the response to administration by mouth is slow, and more of the dye is required. Observations to date indicate that accumulation of methemoglobin can be prevented in adults by oral administration of 0.5 to 1.0 gram of methylene blue per day even when the patient is receiving large doses of sulfanilamide.

Before methylene blue was injected into patients receiving sulfanilamide, compatibility of these two substances was tested in dogs and rabbits. Several times as much methylene blue was injected into experimental animals as is required in humans. Also the dye was injected at a time when the animals were severely toxic from large doses of sulfanilamide ( 1 gram per kilogram per day). No increase in toxicity was evident following intravenous injection of the dye. In order to elicit possible cumulative effects of administration of the combination of drugs one dog was given 0.6 gram sulfanilamide per kilogram per day and 0.27 gram of methylene blue per day by mouth for 4 weeks. No outward evidence of toxicity or abnormal blood changes was observed.

Preliminary experiments with Dr. Anna Dulaney of the University of Tennessee Medical School on mice injected with highly virulent strains of beta hemolytic streptococci indicate that

TABLE I

Effect of various amounts of methylene blue on rate of conversion of methemoglobin to hemoglobin in dogs

\begin{tabular}{|c|c|c|c|c|c|}
\hline \multirow{2}{*}{$\underset{\text { number }}{\text { Dog }}$} & \multirow{2}{*}{$\begin{array}{l}\text { Amount of } \\
\text { methylene } \\
\text { blue } \\
\text { injected }\end{array}$} & \multirow{2}{*}{$\begin{array}{c}\text { Rate of } \\
\text { disappear- } \\
\text { ance of } \\
\text { methemoglobin }\end{array}$} & \multicolumn{3}{|c|}{ Orygen capacity } \\
\hline & & & $\begin{array}{l}\text { Before } \\
\text { nitrite }\end{array}$ & $\begin{array}{c}\text { After } \\
\text { nitrite* }\end{array}$ & $\underset{\text { methylene bluet }}{\text { After }}$ \\
\hline & mom. por & $\begin{array}{c}\text { volumes per cent } \\
\text { per minuts }\end{array}$ & $\begin{array}{l}\text { volumes } \\
\text { per cent }\end{array}$ & $\begin{array}{l}\text { wolumes } \\
\text { per cent }\end{array}$ & $\begin{array}{l}\text { olumes } \\
\text { per cent }\end{array}$ \\
\hline $\begin{array}{l}14 \\
14 \\
21 \\
16 \\
18\end{array}$ & $\begin{array}{r}10 \\
10 \\
10 \\
5 \\
5\end{array}$ & $\begin{array}{l}0.77 \\
0.33 \ddagger \\
0.31 \ddagger \\
0.19 \\
0.25\end{array}$ & $\begin{array}{l}12.8 \\
17.7\end{array}$ & $\begin{array}{l}4.4 \\
7.3\end{array}$ & $\begin{array}{l}17.3 \text { (50 minutes) } \\
13.2 \text { (30 minutes) } \\
17.0 \text { (65 minutes) }\end{array}$ \\
\hline $\begin{array}{r}17 \\
22 \\
19 \\
20 \\
6 \\
17 \\
22 \\
20\end{array}$ & $\begin{array}{l}2 \\
2 \\
1 \\
1 \\
0.5 \\
0.5 \\
0.1 \\
0.1\end{array}$ & $\begin{array}{l}0.23 \\
0.20 \\
0.076 \\
0.14 \\
0.12 \\
0.082 \\
0.049 \\
0.051\end{array}$ & $\begin{array}{l}16.4 \\
12.7\end{array}$ & $\begin{array}{l}6.3 \\
5.5\end{array}$ & $\begin{array}{l}15.4 \text { (60 minutes) } \\
10.6 \text { (95 minutes) }\end{array}$ \\
\hline $\begin{array}{l}\text { Nine control } \\
\text { animals }\end{array}$ & 0 & Average $=0.028$ & & & \\
\hline
\end{tabular}

* Determined at peak of methemoglobin formation.

$\dagger$ Figures in parentheses denote interval between injecting methylene blue and determining oxygen capacity.

I Rate was actually faster than this. Method did not permit accurate determination. 
methylene blue does not interfere with the therapeutic action of sulfanilamide in these animals.

\section{Sulfanilamide methemoglobinemia}

The frequency of methemoglobinemia in patients receiving sulfanilamide has not been determined. We have, however, examined for the presence of methemoglobin the blood of more than one hundred patients who were showing cyanosis from this drug. In this group of patients where the blood was examined within 30 minutes after being drawn and the sulfanilamide concentration was greater than $4 \mathrm{mgm}$. per cent, methemoglobin was found at least in traces (more than 3 per cent of the total pigment) in every blood except two. Table II summarizes data obtained on samples of blood containing more than 15 per cent of methemoglobin and whose sulfanilamide concentration also was determined (11). Most of these samples of blood were from patients who were receiving 0.1 to 0.2 gram of sulfanilamide per kilogram of body weight per day in divided doses at 4-hour intervals. In each case the dose of sulfanilamide had been constant 24 hours prior to collection; in most, it had been constant 48 hours. Where several sets of data are given on one patient, they represent analyses of samples of blood taken on different days, sometimes at widely separated intervals and following change in dosage. No correlation between concentration of sulfanilamide in the blood and intensity of methemoglobinemia is evident in these data.

Evidence that methemoglobin is the principal abnormal pigment in the blood of patients showing cyanosis from sulfanilamide will be published in detail elsewhere but may be summarized as follows. (a) When a freshly drawn sample of blood from such a patient is laked with 4 or 5 volumes of water in a tube of about one inch in diameter and is examined with a hand spectroscope before a 60 to 100 watt frosted light bulb, it usually shows an absorption band in the red region of the spectrum (at $\lambda=630 \mathrm{~m} \mu$ ). In a given sample of blood the intensity of this band is approximately the same as that calculated for methemoglobin from the difference between total pigment and oxygen capacity, this difference being assumed to be owing to methemoglobin alone. Following addition of a buffer solution of $\mathrm{pH} 6.5$ this band is intensified. Addition of sodium
TABLE II

Lack of relationship between concentration of sulfanilamide in the blood and the degree of methemoglobinemia

\begin{tabular}{|c|c|c|c|}
\hline Patient & $\begin{array}{c}\text { Blood } \\
\text { sulfanilamide }\end{array}$ & Methemoglobin & Total pigment \\
\hline L. F. & $\begin{array}{c}\text { mgm. per cent } \\
4 \\
4\end{array}$ & $\begin{array}{c}\text { per cent of } \\
\text { total pigment } \\
22 \\
16\end{array}$ & $\begin{array}{c}\text { volumes } \\
\text { per cent } \\
7.8 \\
7.8\end{array}$ \\
\hline H. L. & $\begin{array}{l}34 \\
50 \\
27 \\
20 \\
17\end{array}$ & $\begin{array}{l}33 \\
25 \\
27 \\
22 \\
20\end{array}$ & 14.6 \\
\hline E. B. & 8 & 29 & 13.4 \\
\hline L. M. & 14 & 17 & 18.1 \\
\hline W. R. S. & 14 & 29 & 15.1 \\
\hline M. A. & $\begin{array}{l}5 \\
6\end{array}$ & $\begin{array}{l}21 \\
29\end{array}$ & 16.5 \\
\hline B. D. & 20 & 25 & 6.4 \\
\hline L. McM. & $\begin{array}{l}7 \\
5\end{array}$ & $\begin{array}{l}22 \\
17\end{array}$ & $\begin{array}{l}11.9 \\
12.4\end{array}$ \\
\hline E. W. & $\begin{array}{l}26 \\
10 \\
12\end{array}$ & $\begin{array}{l}30 \\
30 \\
23\end{array}$ & 14.4 \\
\hline E. J. & $\begin{array}{l}6 \\
5\end{array}$ & $\begin{array}{l}22 \\
25\end{array}$ & 22.0 \\
\hline$T$. & 5 & 23 & 13.9 \\
\hline $\mathbf{Y}$. & $\begin{array}{r}20 \\
9\end{array}$ & $\begin{array}{l}25 \\
25\end{array}$ & \\
\hline H. I. & 5 & 25 & 11.0 \\
\hline J. T. & $\begin{array}{l}9 \\
8\end{array}$ & $\begin{array}{l}33 \\
33\end{array}$ & \\
\hline C. B. & 6 & 20 & \\
\hline B. $\mathrm{T}$. & $\begin{array}{r}3 \\
10 \\
8 \\
6\end{array}$ & $\begin{array}{l}13 \\
30 \\
33 \\
25\end{array}$ & \\
\hline M. L. M. & 5 & 28 & \\
\hline G. $\mathrm{O}$. & 8 & 27 & 18.1 \\
\hline R. L. L. & 14 & 29 & 14.0 \\
\hline B. S. M. & 3 & 26 & \\
\hline O. B. S. & 7 & 22 & \\
\hline B. & $\begin{array}{r}12 \\
7\end{array}$ & $\begin{array}{l}27 \\
30\end{array}$ & 14.2 \\
\hline
\end{tabular}

cyanide or carbonate dissipates it entirely. In an occasional sample of blood there is an absorption band in the red portion of the spectrum (some- 
what nearer the yellow) which is unaffected by alkali or cyanide and which is caused by the presence of sulfhemoglobin. The following statements, therefore, are intended to apply only to those cases in which sulfhemoglobin is absent. (b) The absorption band in the red region of the spectrum is greatly weakened or is entirely dissipated by injection of methylene blue. At the same time the color of the blood changes from reddish brown to a more normal red. Also following injection of methylene blue the oxygen capacity of the blood increases and usually becomes equal to the total pigment concentration (determined spectrophotometrically as cyanmethemoglobin). This important point is illustrated by the data in Table III. (c) Spectrophotometric

\section{TABLE III}

Increase in oxygen capacity of blood of patients following intravenous injection of methylene blue

\begin{tabular}{|c|c|c|c|c|c|c|}
\hline Patient & $\begin{array}{l}\text { Blood } \\
\text { sulfanil- } \\
\text { amido }\end{array}$ & $\begin{array}{c}\text { Total } \\
\text { plgment }\end{array}$ & $\begin{array}{l}\text { Oxygen } \\
\text { capracity }\end{array}$ & $\begin{array}{l}\text { Differ- } \\
\text { ence be- } \\
\text { tween } \\
\text { total } \\
\text { pigment } \\
\text { and } \\
\text { oxygen } \\
\text { capacity }\end{array}$ & $\begin{array}{c}\text { Methe- } \\
\text { moglobin } \\
\text { (By } \\
\text { spectro- } \\
\text { scopic } \\
\text { method) }\end{array}$ & Remarkf \\
\hline H. L.... & $\begin{array}{c}\text { mom. } \\
\text { per cent } \\
23 \\
23\end{array}$ & \begin{tabular}{|c|} 
oolumes \\
per cent \\
13.4 \\
12.5 \\
\\
12.6 \\
12.6
\end{tabular} & $\begin{array}{c}\text { columes } \\
\text { per cent } \\
10.3 \\
12.4\end{array}$ & $\begin{array}{c}\text { wolumes } \\
\text { per cent } \\
3.1 \\
0.1\end{array}$ & \begin{tabular}{|c|} 
nolumes \\
per cent \\
3.2 \\
0.3 \\
\\
3.7 \\
0
\end{tabular} & $\begin{array}{l}\text { Before MB } \\
1 \text { hour after } 13 \propto 1 \\
\text { per cent MB } \\
\text { Before MB } \\
80 \text { minutes after } 10 \text { cc. } \\
1 \text { per cent MB }\end{array}$ \\
\hline L. M.... & 14 & 20.5 & $\begin{array}{l}15.9 \\
16.6\end{array}$ & 5.4 & 3.6 & $\begin{array}{l}\text { Before MB } \\
25 \text { minutes after } 1500 . \\
1 \text { per cent MB }\end{array}$ \\
\hline W. R. S. & 14 & 15.1 & $\begin{array}{l}10.4 \\
13.6\end{array}$ & 4.7 & $\begin{array}{l}4.4 \\
0.7\end{array}$ & $\begin{array}{l}\text { Before MB } \\
45 \text { minutes after } 200 . \\
1 \text { per cent MB }\end{array}$ \\
\hline M. A.... & 6 & $\begin{array}{l}16.5 \\
16.5\end{array}$ & $\begin{array}{l}12.8 \\
16.0\end{array}$ & $\begin{array}{l}3.7 \\
0.5\end{array}$ & $\begin{array}{l}4.8 \\
0.5\end{array}$ & $\begin{array}{l}\text { Before MB } \\
40 \text { minutes after } 1000 . \\
1 \text { per cent MB }\end{array}$ \\
\hline H. I..... & 5 & $\begin{array}{l}11.0 \\
11.0\end{array}$ & $\begin{array}{r}9.0 \\
10.6\end{array}$ & $\begin{array}{l}2.0 \\
0.4\end{array}$ & $\begin{array}{l}2.7 \\
0.3\end{array}$ & $\begin{array}{l}\text { Before MB } \\
75 \text { minutes after } 10 \mathrm{cc} . \\
1 \text { per cent MB }\end{array}$ \\
\hline R.L. L. & $14^{*}$ & $\begin{array}{l}13.0 \\
11.7\end{array}$ & $\begin{array}{r}9.4 \\
11.1\end{array}$ & $\begin{array}{l}3.6 \\
0.6\end{array}$ & $\begin{array}{l}3.8 \\
0.4\end{array}$ & $\begin{array}{l}\text { Before MB } \\
60 \text { minutes after } 5 \mathrm{co} . \\
1 \text { per cent MB }\end{array}$ \\
\hline
\end{tabular}

* Concentration previous day.

$\dagger \mathrm{MB}=$ methylene blue.

measurement of the visible absorption spectrum indicates that oxyhemoglobin and methemoglobin are the only colored substances present in significant amounts in the blood of these patients. Such observations lend no support to the suggestion of Ottenberg and Fox (5) that the dark color of the blood from patients treated with sulfanilamide is owing per se to adsorption by the erythrocytes of a colored derivative of sulfanilamide, formed by irradiation of dilute solutions of the latter. It is interesting to note, however, that the colored derivatives of sulfanilamide described by these workers convert hemoglobin to methemoglobin in vitro.

\section{DISCUSSION}

In 1933, Williams and Challis (7) and Steele and Spink (8) reported that intravenous injection of methylene blue into three patients showing severe poisoning and methemoglobinemia resulting from aniline and aniline derivatives brought about rapid recovery of the patients. Both groups of workers stated that the methemoglobinemia shown by their patients rapidly subsided following injection of the dye. These observations did not receive the attention they deserved, probably because of the emphasis which was placed at that time upon the reverse transformation which accounts for the antidotal action of methylene blue in cyanide poisoning (12). Also, the spectroscopic data of Williams and Challis (7) were not altogether convincing. Nevertheless, their conclusions were correct, and it is necessary to explain how methylene blue may either convert hemoglobin to methemoglobin and thus act as an antidote for cyanide, or hasten the reverse transformation and act as an antidote for methemoglobin-forming substances.

Methylene blue forms methemoglobin by catalytic oxidation (10). The dye reacts directly with hemoglobin to form methemoglobin, and the reduced (leuco) form of methylene blue formed by this reaction reacts with oxygen to regenerate methylene blue. It is not equally clear how methylene blue accomplishes reduction of methemoglobin to hemoglobin. Since each molecule of dye injected effects conversion of many molecules of methemoglobin to hemoglobin, this reaction, too, is catalytic. Here, however, the catalysis is one of reduction, and leuco methylene blue would appear to be the effective reductant. Two possible sources of the leuco methylene blue in the body are reduction of methylene blue in the erythrocytes by enzyme systems present there and reduction of methylene blue in other tissues. Preliminary experiments suggest that the rate of formation of leuco methylene blue in the erythrocytes may not be sufficiently rapid to account for 
all the methemoglobin reduced. Thus it would appear that leuco methylene blue formed in the more actively metabolizing tissues and returned as such to the erythrocytes may play a rôle in reducing methemoglobin to hemoglobin. Experiments designed to test this possibility are in progress.

Owing to the limited time during which methylene blue has been used with sulfanilamide, its clinical value as an adjunct to sulfanilamide therapy can not as yet be assessed. It seems possible that the use of sulfanilamide might be less hazardous in many patients, especially those having respiratory and cardiac involvements, if the accumulation of methemoglobin were prevented. Also, the usefulness of sulfanilamide might be extended by giving larger doses, the methemoglobinemia being controlled by methylene blue.

In conclusion it should be borne in mind that intravenous injection of methylene blue may not be entirely without ill effects. Gregoire (13) has reported experiments on rats which suggest that patients kept in oxygen tents should be given methylene blue intravenously only with caution. Nadler, Green, and Rosenbaum (14), on the basis of electrocardiographic studies, state that methylene blue depresses the ventricular musculature and warn against its indiscriminate use. Also, hemolytic anemia has been observed in dogs following intravenous injection of this dye (15). These reports of toxic effects, however, were associated with much greater amounts of methylene blue ( 20 to $50 \mathrm{mgm}$. per kilogram of body weight) than is required to control sulfanilamide methemoglobinemia. Nevertheless, even small amounts of the dye should be injected carefully and slowly. Leakage of the dye around the vein may produce a painful infiltration, and too rapid injection may produce hives and a severe burning sensation of the lips.

\section{SUM MARY}

The principal abnormal pigment in the blood of patients showing cyanosis from sulfanilamide appears to be methemoglobin.

Patients whose functionally active blood pigment is decreased 15 to 30 per cent by formation and accumulation of methemoglobin are not uncommon. Higher concertrations of methemoglobin are occasionally encountered.
The extent to which methemoglobin accumulates is not proportional to the concentration of sulfanilamide in the blood.

Following intravenous injection of small amounts of methylene blue, methemoglobin rapidly disappears from the blood and is replaced by an equivalent amount of hemoglobin.

Observations on animals which preceded the clinical ones are described. A possible mechanism by which methylene blue accomplishes conversion of methemoglobin to hemoglobin is outlined.

The valuable assistance of Charles Anderson, Jane Erganian, and Nanette Miller Wendel and the cooperation of Dr. J. B. McElroy, Dr. Gilbert Levy, and the Staff of the Isolation Division of the John Gaston Hospital, Memphis, is acknowledged.

\section{BIBLIOGRAPHY}

1. Paton, J. P. J., and Eaton, J. C., Sulfhemoglobinemia and methemoglobinemia following administration of $p$-aminobenzenesulfonamide. Lancet, 1937, 1, 1159.

2. Bensley, E. H., and Ross, J. B., Methemoglobinemia due to sulfanilamide therapy. Canad. M. A. J., 1937, 37, 62.

3. Mull, J. W., and Smith, J. T., Effect of sulfanilamide on the oxygen capacity of the blood. J. A. M. A., 1938, 110, 439.

4. Marshall, E. K., Jr., and Walzl, E. M., On the cyanosis from sulfanilamide. Bull. Johns Hopkins Hosp., 1937, 61, 140.

5. Ottenberg, R., and Fox, C. L., Jr., Explanation for the cyanosis of sulfanilamide therapy. Proc. Soc. Exper. Biol. and Med., 1938, 38, 479.

6. Chesley, L. C., Cyanosis without sulf- or methemoglobinemia in patients receiving sulfanilamide treatment. J. Clin. Invest., 1938, 17, 445.

7. Williams, J. R., and Challis, F. E., Methylene blue as an antidote for aniline dye poisoning. J. Lab. and Clin. Med., 1933, 19, 166.

8. Steele, C. W., and Spink, W. W., Methylene blue in the treatment of poisonings associated with methemoglobinemia. New England J. Med., 1933, 208, 1152.

9. Hauschild, F., Die Wirkung des Katalysins (Thionin) bei der Methämoglobinvergiftung. Arch. f. exper. Path. u. Pharmakol., 1937, 184, 458.

10. Warburg, O., Kubowitz, F., and Christian, W., Uber die katalytische Wirkung von Methylenblau in lebenden Zellen. Biochem. Ztschr., 1930, 227, 245.

11. Marshall, E. K., Jr., Determination of sulfanilamide in blood and urine. Proc. Soc. Exper. Biol. and Med., 1937, 36, 422.

12. Wendel, W. B., Methylene blue, methemoglobin, and cyanide poisoning. J. Pharmacol. and Exper. Therap., 1935, 54, 283. 
Chen, K. K., Rose, C. L., and Clowes, G. H. A., Comparative values of several antidotes in cyanide poisoning. Am. J. M. Sc., 1934, 188, 767.

13. Gregoire, P. E., Action of methylene blue on body temperature and metabolism. J. Exper. Med., 1931, 54, 827.

14. Nadler, J. E., Green, H., and Rosenbaum, A., Intravenous injection of methylene blue in man, with reference to its toxic symptoms and effect on the electrocardiogram. Am. J. M. Sc., 1934, 188, 15.

15. Huyghebaert, E., Action hémolytique du bleu de méthylène. Arch. Internat. de pharmocodyn. et de thérap., 1924, 29, 405.
Wendel, W. B., and Hefley, M. L., Methylene blue as an agent for reducing red blood cell count. Proc. Soc. Exper. Biol. and Med., 1934, 31, 973.

\section{ADDENDUM}

Since this paper was accepted for publication the method used for methemoglobin determination has been described (J. Lab. and Clin. Med., 1938, 24, 96).

Also Hartmann, Perley, and Barnett (J. Clin. Invest., $1938,17,699$ ) have published results of their observations on methemoglobinemia resulting from sulfanilamide, and the effect of methylene blue upon this. 